\title{
Diagnostic Approach to Neuroendocrine Neoplasms of the Gastrointestinal Tract and Pancreas
}

\author{
Silvia UCCELLA ${ }^{1}$, Fausto SESSA ${ }^{1}$, Stefano LA ROSA ${ }^{2}$ \\ 'Department of Surgical and Morphological Sciences, University of Insubria, VARESE, ITALY, \\ ${ }^{2}$ Department of Pathology, Ospedale di Circolo, VARESE, ITALY
}

\begin{abstract}
The gastroenteropancreatic (GEP) system is the site of origin of about two thirds of all neuroendocrine neoplasms (NENs) of the human body. GEP-NENs encompass a wide spectrum of entities, from very indolent tumors to highly aggressive carcinomas. They represent a challenge for the oncologist and a correct diagnostic approach is crucial for the management of patients. The nomenclature and classification of these tumors have been a matter of debate for more than a century, since their first description by Siegfried Oberdorfer. The last WHO classification provided a robust and easy-to-use tool to prognostically stratify GEP-NENs, based on morphological aspects and on proliferation rate. This review examines current approaches to the diagnosis and prognostic classification of GEP-NENs, focusing on the critical use of morphological parameters and immunohistochemical stainings, including diagnostic, site-specific and prognostic markers. The key issues of the current classification are addressed, including the emerging topics about cases with discordant morphology and proliferative index. Finally, we attempted to highlight the diagnostic pitfalls and the caveats in the use of immunohistochemical stains.
\end{abstract}

Key Words: Neuroendocrine tumors, Gastrointestinal tract, Pancreas, Diagnosis

\section{BACKGROUND}

Neuroendocrine neoplasms (NENs) are a heterogeneous group of epithelial neoplastic proliferations arising in a large number of body organs. Irrespectively of their primary site and of their grade of differentiation, neoplastic cells share features of neural and endocrine differentiation: they present secretory granules, synaptic-like vesicles and are potentially capable of producing amine and/or peptide hormonal products. About two thirds of NENs arise in the gastrointestinal tract and pancreas (1).

Gastroenteropancreatic (GEP) NENs are relatively rare tumors, although their incidence is steadily increasing and epidemiological studies report a present estimated prevalence of $35 / 100.000(1,2)$. The improvement of diagnostic techniques has led to an increased number of diagnosed cases and, in contrast with the past, most of the tumors belong to the so called "nonfunctioning" category, as they are not associated with symptoms and signs of hormone hypersecretion. Among "functioning" GEP-NENs, gastrinoma, associated with ZollingerEllison syndrome, and insulinoma, associated with insulin hypersecretion syndrome, are the most frequent ones. Carcinoid syndrome, due to serotonin hypersecretion by intestinal and, more rarely, pancreatic NETs is a rare

(Turk Patoloji Derg 2015, 31(Suppl):113-127)

Received : 23.05.2015 Accepted : 01.06.2015 finding, as only neoplasms widely metastatic to the liver are associated with this syndrome $(3,4)$.

The high heterogeneity of the biological and clinical features of GEP-NENs represents a challenge for the oncologist and a correct diagnostic approach is crucial for the management of patients. GEP-NENs encompass a wide spectrum of neoplasms, from "benign" or very indolent tumors to highly aggressive carcinomas. Accordingly, the morphological features of these neoplastic proliferations are variable and must be carefully identified by the pathologist in order to produce a correct and complete histopathological report, which will be the starting point for the optimal treatment and follow up of each patient (5).

The most critical aspects in diagnosing a GEP-NEN can be summarized as follows; i) recognizing the malignant/ aggressive potential in a well to moderately differentiated tumor; ii) identifying the neuroendocrine nature of a poorly differentiated high grade carcinoma; iii) correctly integrating the morphological aspects with other prognostic indicators, such as proliferative rate, for a better definition of clinically aggressive tumors. In the management of these diagnostic challenges, a comprehensive morphological and immunohistochemical appraisal represents the most reliable tool for the pathologist.

Correspondence: Stefano LA ROSA

Department of Pathology, Ospedale di Circolo

viale Borri 57, 21100 VARESE, ITALY

E-mail: stefano.larosa@ospedale.varese.it Phone: +39 0332270601 


\section{MORPHOLOGICAL FEATURES}

GEP-NENs are morphologically heterogeneous. A useful and effective framework for the diagnosis is based on the differentiation degree of these neoplasms, which are subdivided in two broad categories: well-differentiated neuroendocrine tumors and poorly differentiated neuroendocrine carcinomas (Table I). A third category is represented by neoplasms with both a neuroendocrine and a non-neuroendocrine component (usually adenoma, adenocarcinoma or squamous cell carcinoma), which are currently classified as mixed adenoneuroendocrine carcinomas (MANECs) (6-8).

Well differentiated neuroendocrine tumors (WD-NETs) are generally well circumscribed, sometimes encapsulated (in the pancreas), tumors with a uniform cut surface. Histologically, they are characterized by an organoid proliferation of uniform cells, with moderately abundant granular and eosinophilic cytoplasm containing numerous secretory granules (Figure 1A). Oncocytic and clear cell features may be present (Figure 1B,C) $(9,10,11)$. Nuclei are generally round, with clumped or finely granular ("salt and pepper") chromatin and small nucleoli. Nuclear atypia may be up to moderate in some cases, and pleomorphic cells with large atypical nuclei may be present (Figure 1D), but this is not necessarily related to the biologic aggressiveness of the tumor (12). According to Soga and Tazawa (13), the architectural pattern of growth can be subclassified as follows: insular solid type, with nests of small to medium size (type A), trabecular type (type B), glandular type (type C) or diffuse type (type D) (Figure 2A-D). Different architectural types may be related to the site of origin: ileal and appendiceal neoplasms are mostly type A, whereas rectal tumors are frequently type $\mathrm{B}$, and type $\mathrm{C}$ is a frequent feature of ampullary tumors. As WD-NETs may behave in a malignant fashion, it is important to look for morphological clues that can be associated with tumor aggressiveness, such as the invasion of blood and lymphatic vessels and of perineural spaces, the infiltration of the capsule, if present, and of adjacent tissues. Another mandatory evaluation is mitotic count, together with the assessment of the Ki67 proliferative index (see "Immunohistochemistry") (5).

GEP WD-NETs should be differentiated from a number of epithelial and non-epithelial neoplasms, depending on the site of origin. In the pancreas the most challenging differential diagnosis are acinar cell carcinoma and solid pseudopapillary tumor. Adenocarcinomas and the epithelioid variant of gastrointestinal stromal tumor (GIST) should be included among the differential diagnoses in the ampullary region and, more in general, in the whole tubular gastrointestinal tract. The morphological aspects, together with a proper immunohistochemical panel, lead to the correct diagnosis.

Poorly differentiated neuroendocrine carcinomas (PD-NECs) are highly aggressive neoplasms. Macroscopically, they are poorly circumscribed, may show large areas of necrosis and hemorrhage and show deep infiltration of the bowel wall or the peripancreatic tissue (in the pancreas) and are frequently metastatic when diagnosed. Microscopically, PD-NECs are characterized by a solid proliferation of cells, in large nests or in sheets with large areas of "geographic chart" necrosis (Figure 3A). Like lung tumors, they have traditionally been divided into the small and large cell subtypes, based on the morphological features of the neoplastic cells. Small cell

Table I: Morphological features of well and poorly differentiated neuroendocrine neoplasms

\begin{tabular}{|l|l|l|l|}
\hline & \multicolumn{1}{|c|}{ WD-NET } & \multicolumn{1}{c|}{ Large cell type } \\
\hline Pattern of growth & \multicolumn{1}{|c|}{ Small cell type } & \multicolumn{1}{c|}{ Insular, trabecular, acinar* } & Diffuse/organoid \\
\hline Cell size & Medium & Diffuse & Large \\
\hline Cytoplasm & $\begin{array}{l}\text { Moderately abundant } \\
\text { Finely granular } \\
\text { Eosinophilic }\end{array}$ & Small/medium & Scant \\
Eoundant \\
Nucleus & $\begin{array}{l}\text { Round } \\
\text { Dispersed chromatin ("salt and pepper") }\end{array}$ & $\begin{array}{l}\text { Round or oval } \\
\text { Hyperchromatic }\end{array}$ & $\begin{array}{l}\text { Round } \\
\text { Vesicular }\end{array}$ \\
\hline Nucleolus & Small & Incospicuous & Evident \\
\hline Necrosis & Absent or focal & Large areas & Large areas \\
\hline Mitosis & $0-20$ mitoses x10HPF & $>20$ mitoses x10HPF & $>20$ mitoses x10HPF \\
\hline Ki67 index & $<20 \%$ & $>20 \%$ & $>20 \%$ \\
\hline
\end{tabular}

*: according to the architectural patterns proposed by Soga and Tazawa (13 and Figure 2), WD-NET: Well differentiated neuroendocrine tumor, PD-NEC: Poorly differentiated neuroendocrine carcinoma, HPF: High power field. 


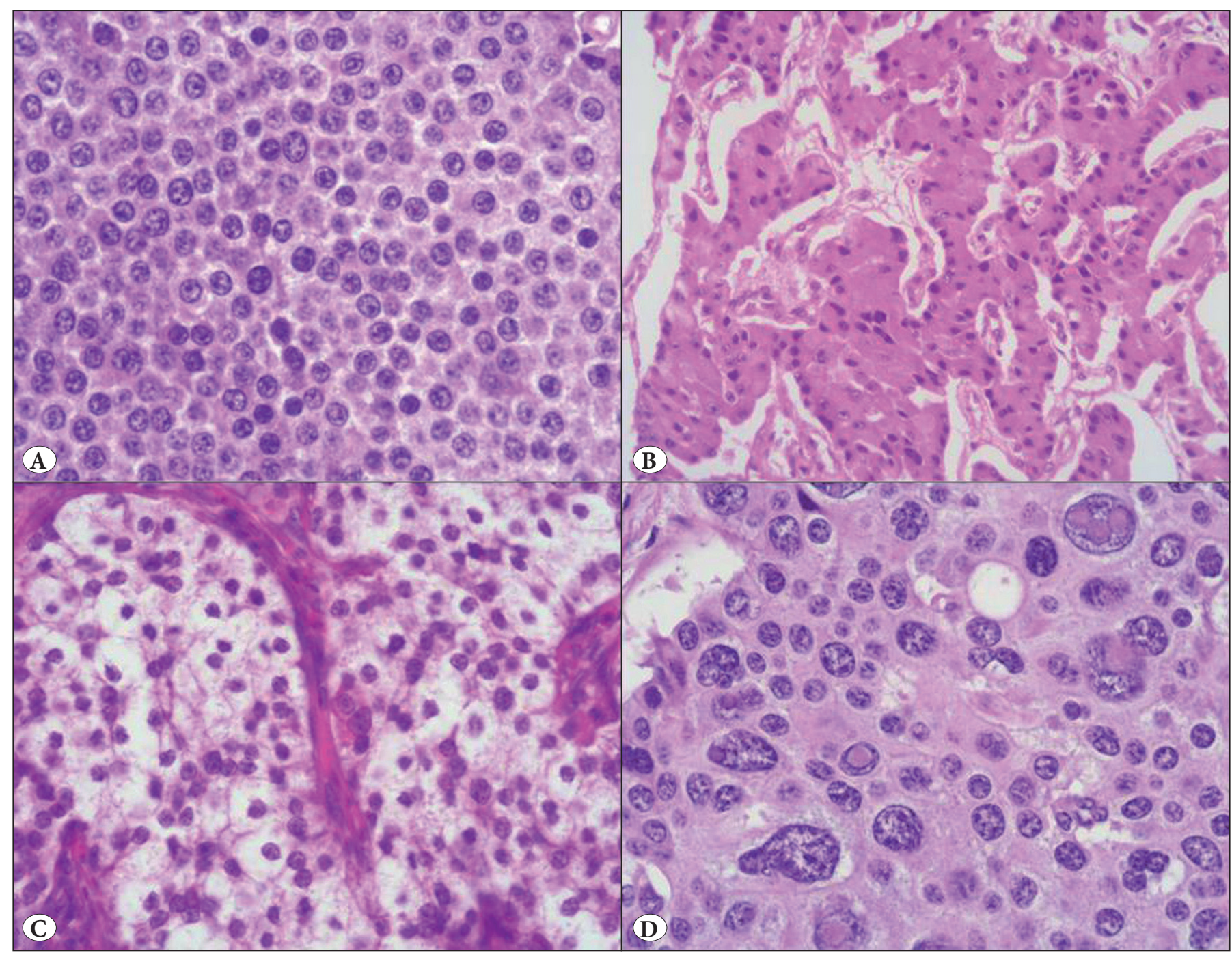

Figure 1: A) Well differentiated neuroendocrine tumor (WD-NET) composed of uniform cells, with moderately abundant granular and eosinophilic cytoplasm. Nuclei are round, with clumped and finely granular ("salt and pepper") chromatin and small nucleoli. B) Example of an oncocytic WD-NET of the pancreas showing cells with abundant eosinophilic cytoplasm. C) Appendiceal clear cell WD-NET composed of cells with a central located nucleus and abundant foamy microvesicular clear cytoplasm. D) Ileal WD-NET showing several pleomorphic cells.

carcinomas (Figure 3B) are composed of small to mediumsized (2-4 times the size of a small lymphocyte), round to oval cells with scant cytoplasm, indistinct cell borders and hyperchromatic nuclei with inconspicuous nucleoli. Large cell subtypes (Figure 3C) are composed of large cells with vesicular nuclei showing prominent nucleoli and abundant eosinophilic cytoplasm. Although tumor cells grow forming sheets or large nests, in the large cell subtype a more structured organoid architecture can be observed. Mitotic figures are extremely frequent, as well as apoptotic bodies, vascular and perineural infiltration. The neuroendocrine nature of the neoplastic proliferation has to be confirmed by immunohistochemical analyses (see below), as the differential diagnosis includes a number of non-endocrine epithelial neoplasms, as well as, although very rarely, other poorly differentiated tumors such as PNET, Ewing sarcoma, desmoplastic small round cell tumors, and myeloid and lymphoid leukemia.

Mixed adenoneuroendocrine carcinomas (MANECs), as defined by the most recent WHO classification of gastrointestinal tumors (6), are neoplasms with both a neuroendocrine and an epithelial non-neuroendocrine component, each representing at least $30 \%$ of the tumor mass (Figure 4A-C). The spectrum of mixed neoplasms is wide and encompasses all the possible combinations between neuroendocrine neoplasms (NETs and NECs) and other epithelial tumors (adenomas, adenocarcinomas 


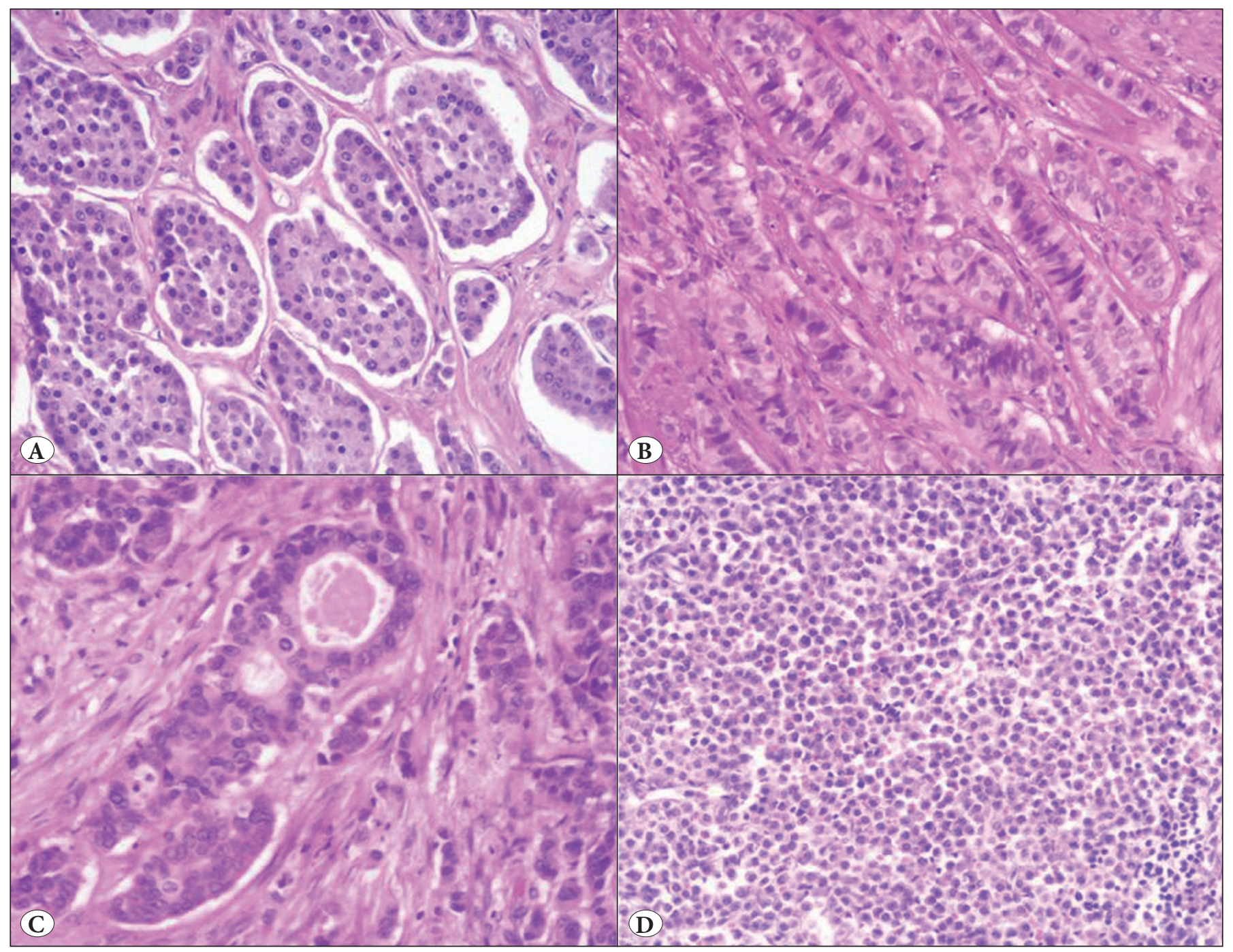

Figure 2: Architectural patterns of growth defined according to Soga and Tazawa (13): A) Insular solid growth with small to medium sized nests in an ileal well differentiated NET (WD-NET) (Type A). B) Rectal WD-NET with trabecular pattern of growth (type B). C) Ampullary WD-NET forming tubular and pseudo glandular structures (type C). D) Solid sheets of neoplastic cells in a pancreatic WD-NET (type D).

and squamous cell carcinomas) arising in the in the tubular digestive tract and pancreas. Consequently, the biological and clinical behavior of MANECs is variable and these tumors need to be stratified into prognostic categories according to the grade of malignancy of each component (8) (see "Classification" later in the text).

\section{IMMUNOHISTOCHEMISTRY}

\section{Identification of the Neuroendocrine Differentiation}

The most useful immunohistochemical markers for the demonstration of the neuroendocrine nature of a neoplasm are chromogranin A and synaptophysin $(5,14,15)$. The immunostaining for these two markers is essential in the diagnosis of PD-NECs, in which the neuroendocrine phenotype may be not evident on routine hematoxylin and eosin stained slides. It is also recommended in WD-NETs, particularly in cases in which the diagnosis on morphology alone is not straightforward and in tumors presenting as metastatic disease from an unknown primary $(14,15)$. Synaptophysin immunoreactivity is generally diffuse in both WD-NETs and PD-NECs (Figure 5A,B) whereas chromogranin A expression in PD-NECs, especially in the small cell subtype, may sometimes be absent or focal and the pattern of immunoreactivity may show a peculiar perinuclear dot-like staining, instead of the granular diffuse pattern observed in WD-NETs (Figure 5C,D). For this reason, care must be taken in the use of chromogranin- $\mathrm{A}$ alone in the diagnostic pathway of PD-NECs. Other 


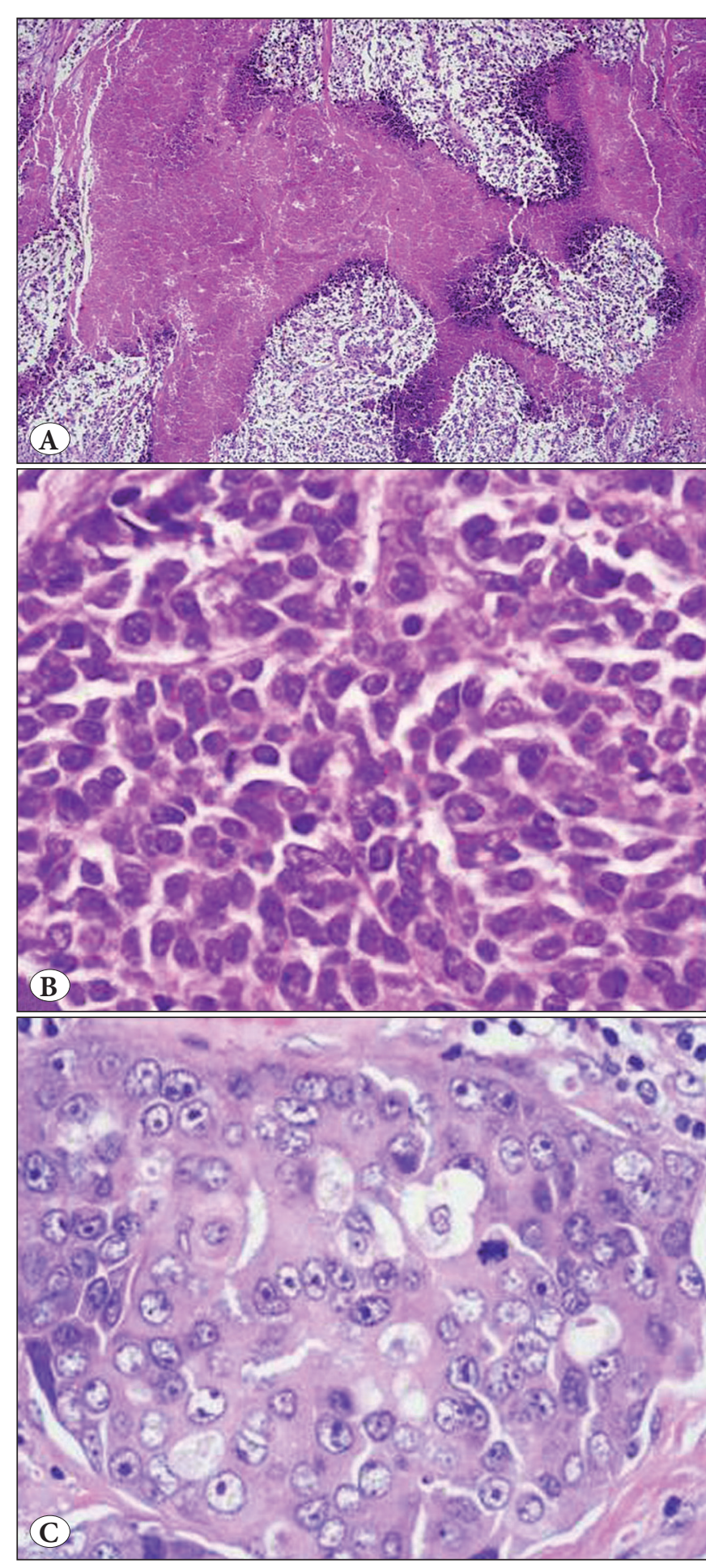

Figure 3: Morphological features of poorly differentiated neuroendocrine carcinomas (PD-NECs). A) Large areas of "geographic chart" necrosis are frequent in these neoplasms. B) Small cell subtype of PD-NEC is composed of neoplastic cell of small size, with indistinct cell borders, hyperchromatic nuclei with incospicuous nucleoli and scant cytoplasm. C) Large cell subtype is composed of large cells with abundant eosinophilic cytoplasm and large vesicular nuclei with prominent nucleoli. general neuroendocrine markers have been proposed over time, such as neuron specific enolase (NSE), protein gene product 9.5 (PGP 9.5), CD56 (neural cell adhesion molecule, N-CAM) and CD57 (leu7) (16). However, the routine use of these markers has been discouraged, as their specificity is questionable $(15,17-19)$, albeit they can be useful in the diagnostic management of those PD-NECs in which chromogranin A is expressed less and synaptophysin immunoreactivity is the only clue to a neuroendocrine differentiation. On the other hand, while synaptophysin has proved to be a highly sensitive marker for neuroendocrine differentiation, its specificity is reduced by the fact that some non-neuroendocrine neoplasms, such as adrenal cortical adenomas and carcinomas and solid pseudopapillary tumor of the pancreas are also immunoreactive for this marker (16). Consequently, a minimum of two positive neuroendocrine markers has been recommended to substantiate the neuroendocrine differentiation of a tumor $(5,14)$.

Achaete-scute homolog 1 (ASH1), a transcription factor involved in the development of fetal lung neuroendocrine cells, has been recently proved to be a marker of lung and extra-pulmonary PD-NECs (20). ASH1 expression is almost exclusively restricted to PD-NECs while it is practically absent in WD-NETs, with the only exception of rare lung carcinoids showing a focal and faint immunoreactivity. For this reason, ASH1 has been proposed as a marker of poor differentiation in the workup of NENs (20) and ASH1 immunohistochemistry may be a useful tool in the diagnostic pathway of small biopsy specimens when morphology is compromised and is not sufficient to make a diagnosis of PD-NEC.

\section{Hormonal Markers}

Immunohistochemical staining may also be used to detect hormonal amines or peptides. However, a practical diagnostic approach does not require routine detection of hormonal products, even in "functioning" tumors, as the clinical syndrome and not the immunohistochemical demonstration of hormone production defines the functional nature of a GEP-NEN. However, a minimal panel of markers, composed of pancreatic hormones (insulin, glucagon, somatostatin, pancreatic polypeptide), gastrin, and serotonin may be useful for a better evaluation of the clinical profile of the patient $(5,14,21)$.

\section{Assessing the Proliferative Rate}

Proliferative rate is a cornerstone in the evaluation of the histological grade of neuroendocrine tumors. According to the ENETS proposal $(22,23)$, the current WHO 


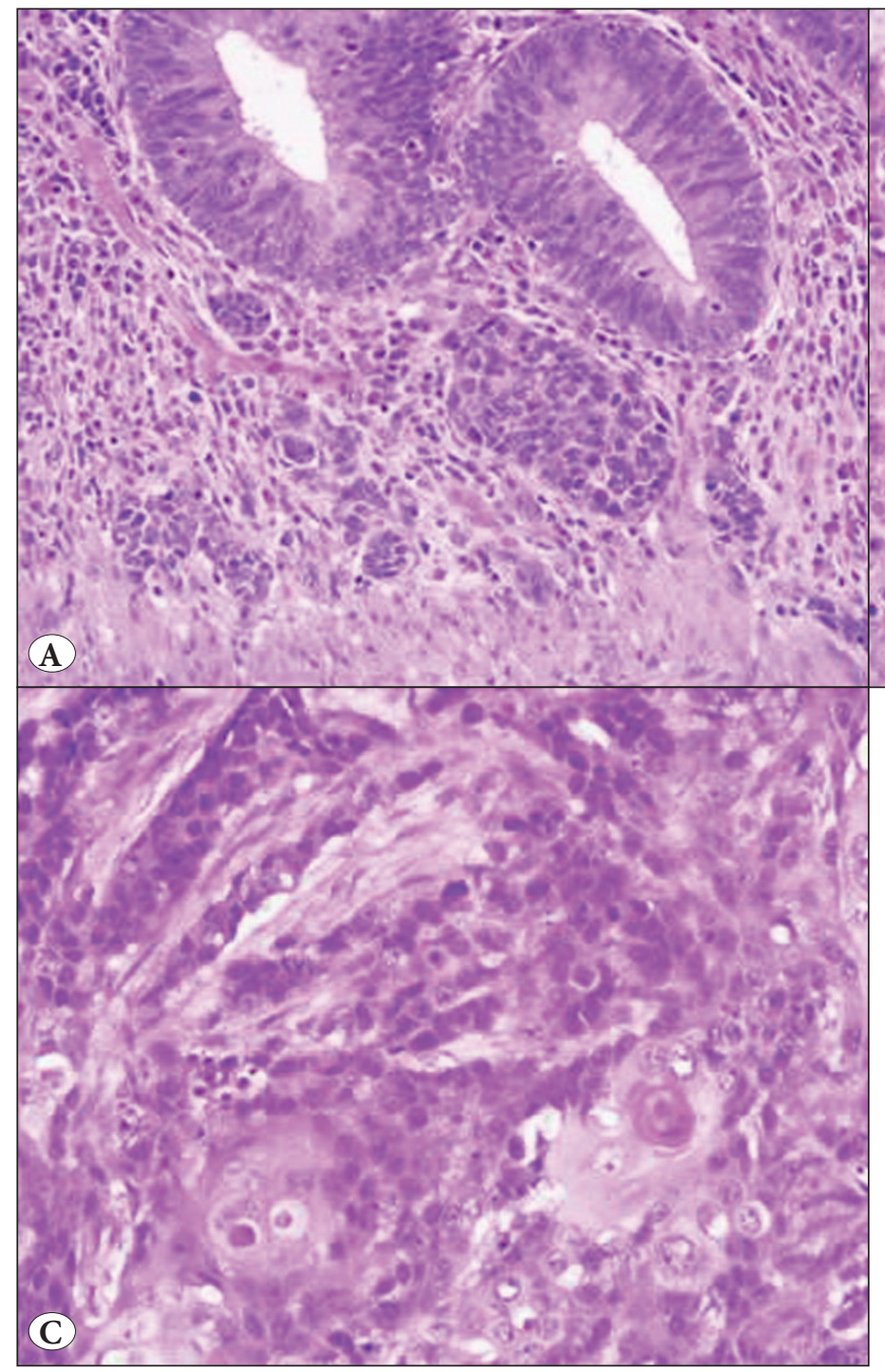

classification has adopted a grading system based on the proliferation fraction, intended both as mitotic and as Ki67 index (6).

In routine surgical pathology practice, mitotic index is traditionally evaluated by counting the number of mitoses per 10 high power fields (HPFs) in hematoxylin-eosin stained sections. However, for NENs, and especially for WDNETs, the recommendation is to express the mitotic index after counting at least 50 HPFs in hot spot areas (24). It has been recently demonstrated that the evaluation of mitotic count using phosphohistone $\mathrm{H} 3$ ( $\mathrm{PHH} 3$ )-immunostained sections improved the inter-observer reproducibility in mitotic rate assessment and grade assignment of WD-NETs in both cytological and histological specimens $(25,26)$.

Ki67 protein expression is strictly associated with cell proliferation and is detectable in the cell nucleus during all

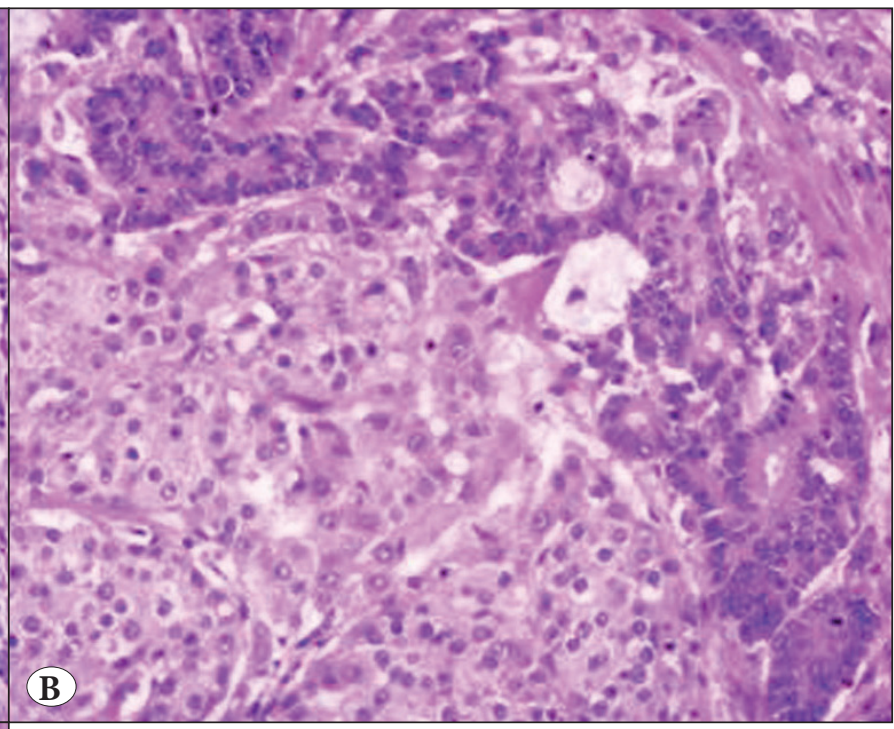

Figure 4: Mixed adenoneuroendocrine carcinomas (MANECs) are neoplasms with both a neuroendocrine and an epithelial non-neuroendocrine component, each representing at least 30\% of the tumor mass. A) MANEC composed of tubular adenoma and small cell neuroendocrine carcinoma. B) MANEC composed of moderately differentiated adenocarcinoma (right upper corner) and large cell neuroendocrine carcinoma. C) MANEC composed of squamous cell carcinoma and poorly differentiated neuroendocrine carcinoma.

active phases of the cell cycle (G1, S, G2, and M), whereas it is absent from resting cells (G0). This makes Ki67 antigen a reliable marker for assessing the growth fraction of a cell population (27). MIB-1 antibody is the reference monoclonal antibody for detecting Ki67 antigen in formalinfixed and paraffin-embedded tissue samples. The WHO grading requires the assessment of the percentage of Ki67immunoreactive cells on a total of 500-2000 neoplastic cells counted in the areas of higher nuclear labeling ("hot spots"). Different methods for assessing the Ki67 index can be used, including eye-balling estimation, automated counting by image analyzer, manual eye-counting (eye under a microscope without a grid), and manual count of cameracaptured/printed image. The accuracy and reproducibility of all these methods have been evaluated in a recently published paper and eye-balling evaluation, although least expensive and fastest (average time $<1 \mathrm{~min}$ ) has showed poor 


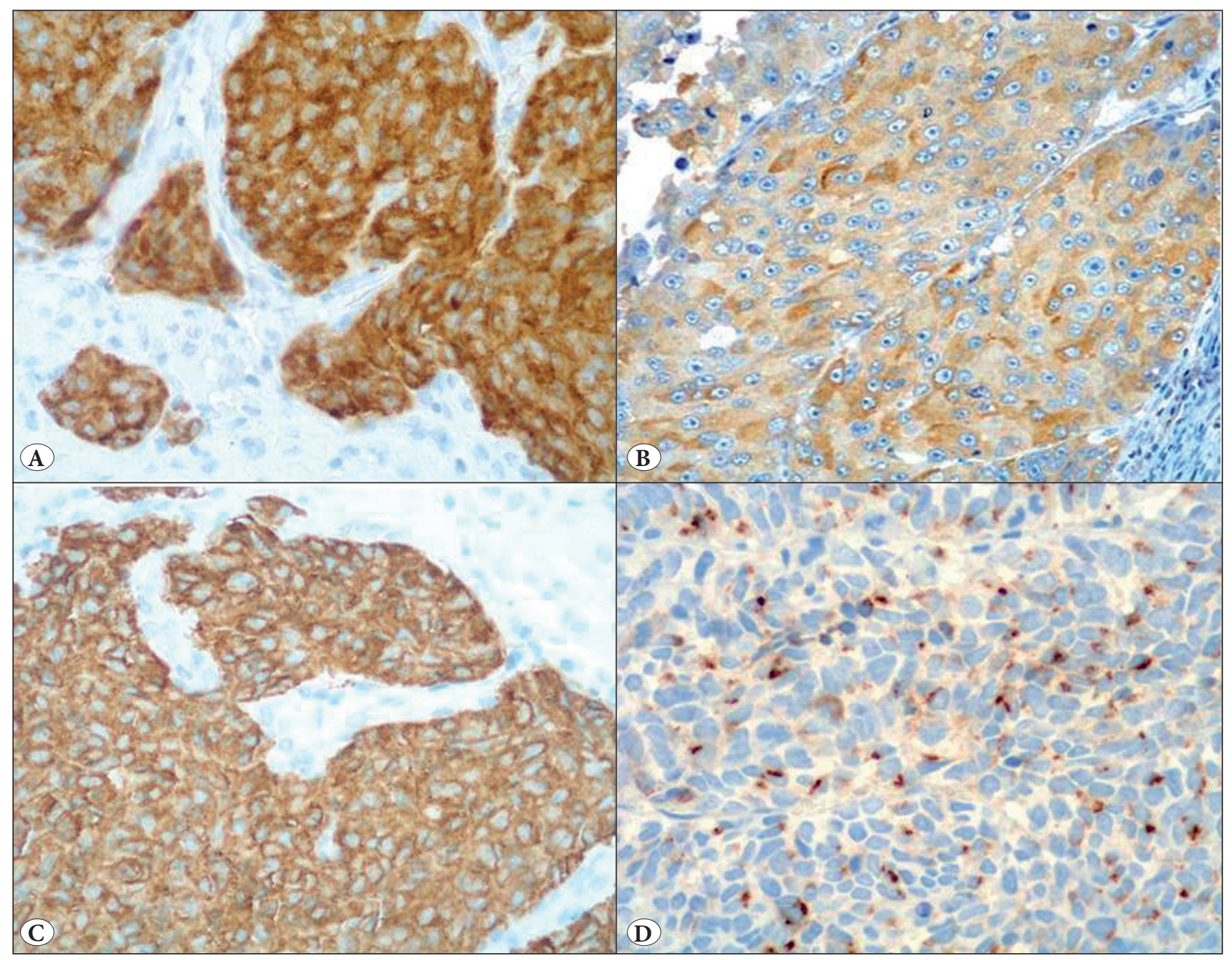

Figure 5: Synaptophysin is generally strongly and diffusely expressed by both well differentiated neuroendocrine tumors (A) and poorly differentiated (B) neuroendocrine carcinomas. Chromogranin A is strongly and diffusely expressed in well differentiated neuroendocrine tumors (C). In poorly differentiated neuroendocrine carcinomas, especially in the small cell subtype (D), chromogranin A may be focally expressed with a paranuclear dot-like patter of immunoreactivity.

reliability and reproducibility, whereas automated counting has turned out to be the most expensive, the least practical, and showed inaccuracies in overcounting unwanted cells. Manual eye count was poorly reproducible, while cameracaptured/printed image was the most reliable, practical and highest reproducible method (28).

\section{Site-Specific Markers}

GEP-NENs may present as metastatic disease to the liver, lymph nodes or other organs and in $30 \%$ of the cases the primary is occult (29). This represents a challenging clinical situation, in that often therapeutic options also depend on the site of origin of the NEN and the pathologist should make every attempt to give some indication about a possible primary site. In recent years, the search for site-specific markers to use in the diagnostic pathway of metastases from occult NENs has been greatly expanded. A significant number of relatively new indicators, mainly represented by transcription factors involved in the development of fetal neuroendocrine cells, have been identified.

CDX2 immunoreactivity points towards an intestinal origin $(30,31)$. PDX1 has been suggested as a marker of pancreatic origin (32). ISL1, first identified as a marker of pancreatic origin $(33,34)$, has also recently been indicated in rectal NETs $(35,36)$. TTF1 is a marker of pulmonary differentiation and may identify metastatic NETs of lung origin, being negative in NETs of gastrointestinal and pancreatic origin $(37,38)$. PAX 8 has been suggested as a 
marker of pancreatic origin (39), but it shows low specificity being also expressed in gastric, duodenal, appendiceal and rectal NETs $(39,40)$.

Although these markers may be useful to search for a primary occult WD-NET, they must be used with extreme caution in the diagnostic pathway of metastases from occult PD-NECs, since they may express these transcription factors independently of the site of origin. TTF1 expression can be frequently detected in extra-pulmonary PD-NECs (38), whilst CDX2 immunoreactivity can also be found in lung PD-NECs, especially in the large cell subtype (30). ISL1, commonly considered as a marker of pancreatic origin, has recently been found in several extra-pancreatic PD-NECs (41).

Recently, the use and performance of a 92-gene molecular cancer classifier has been explored for determining the site of origin of neuroendocrine tumors (42). Four genes were found to be good discriminators for tumor typing and 15 genes for tumor subtyping. These new and preliminary findings need to be confirmed prior to entering in the routine pathological workup (42).

\section{Somatostatin Receptors}

Somatostatin receptor scintigraphy including single photon emission tomography (SPECT) with ${ }^{111}$ In-DTPA-octreotide has long been considered the first choice imaging modality for NENs. However, in the last ten years, many different somatostatin analogs labeled with Gallium-68 have been introduced for the diagnostic work-up of GEP NENs with positron emission tomography/computer tomography (PET/ CT) imaging $(43,44)$. However, in specific clinical settings the status of somatostatin receptors may only be evaluable in tissue specimens, especially when patients did not undergo nuclear medicine imaging during the clinical diagnostic workup or when NENs are incidentally discovered during surgery performed for other reasons. In these situations, the evaluation of somatostatin receptor expression can be made immunohistochemically on the tumor tissue. Although specific antibodies for the various subtypes of somatostatin receptors do exist $(45,46)$, those widely diffuse among laboratories are directed against the receptor subtype $2 \mathrm{~A}$. Immunoreactivity for somatostatin receptor $2 \mathrm{~A}$ is variably present in GEP-NENs and its assessment according to the score proposed by Volante et al. shows a strong correlation with scintigraphy imaging (Figure 6A-D) (47).

\section{Prognostic Markers}

\section{Well Differentiated Neuroendocrine Tumors}

In addition to proliferative grade and morphological parameters traditionally considered as prognostic markers (i.e. vascular and perineural invasion, size, necrosis, etc.), new prognosticators have recently been proposed. However, most of them have been investigated mainly in pancreatic WD-NETs and their prognostic role in WD-NETs of the gut still has to be ascertained.

Cytokeratin 19 (CK19) is an acidic cytokeratin typically expressed in exocrine cells of the human adult pancreas, including duct and centroacinar cells, while it is lacking in normal endocrine cells of pancreatic islets $(48,49)$. Aberrant CK19 expression was found to be an independent prognostic marker in WD-NETs of the pancreas (50, 51). However, this finding was not confirmed in our series, in which the expression of CK19, although more frequently observed in aggressive NETs, did not result as an independent prognostic marker in multivariate analysis (52). Moreover, it appeared that the sensitivity and specificity of the anti-CK19 antibodies in detecting aggressive pancreatic WD-NETs depend on the clone employed (52). The authors believe that CK19 expression should not be routinely investigated, but may be used in selected cases to better evaluate the possibility of a more aggressive potential of a pancreatic WD-NET.

CD117 (C-Kit) has been reported to be a marker with prognostic significance in pancreatic NETs. It was found to be an independent prognostic marker in aggressive pancreatic NETs (53).

The death domain-associated proteins genes DAXX and ATRX encode for proteins involved in chromatin remodeling, which have been detected in $40 \%$ of pancreatic NETs. Mutations of DAXX and ATRX along with chromosome instability and the loss of DAXX and ATRX proteins has been associated with tumor stage and metastasis, reduced time of relapse free survival and decreased time of tumor associated survival (54).

In a recent study, high frequency of gene-specific methylation and low copy number alterations percentages as well as LINE-1 hypomethylation were significantly associated with stage IV and with a poor prognosis in grade 1 and grade 2 pancreatic NETs (55). These new findings suggest that epigenetic alterations such as gene methylation and chromosomal instability may play a role in tumor aggressiveness and may be considered as potential markers of malignancy in pancreatic NETs. 


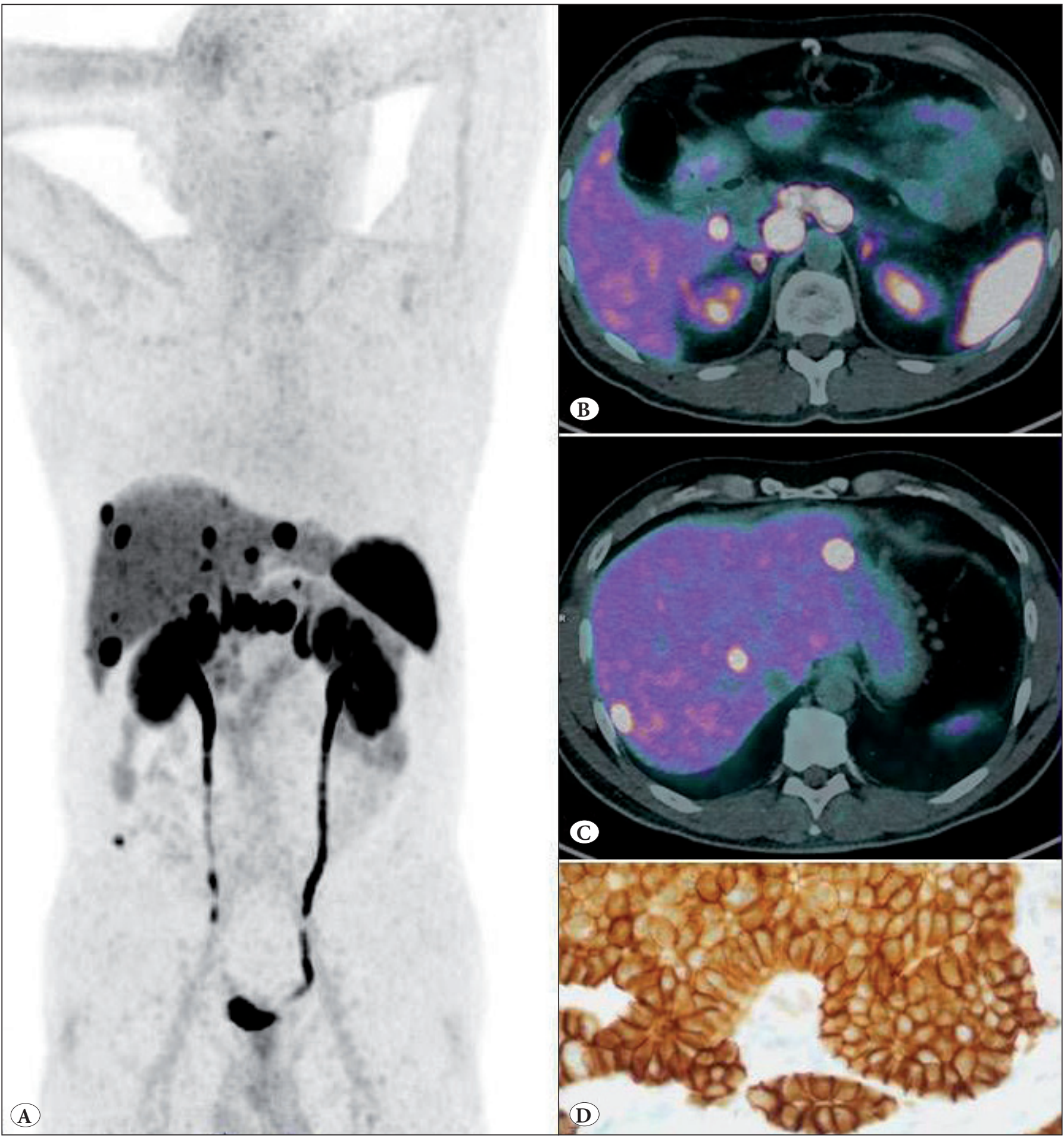

Figure 6: ${ }^{68} \mathrm{Ga}$-DOTANOC PET/CT performed in a 50-year old man. Maximum Intensity projection (MIP) image (A) and transaxial fused images showing intense tracer uptake in a pancreatic neuroendocrine tumor as well as in peri-pancreatic and paracaval lymph nodes (B) and liver metastases (C) (courtesy of Prof. Vittoria Rufini, Catholic University, Rome, Italy) (D) Tumor cells showed intense membrane immunoreactivity for somatostatin receptor $2 \mathrm{~A}$. 


\section{Poorly Differentiated Neuroendocrine Carcinomas}

GEP-NECs are high grade cancers associated with a poor prognosis. However, the outcome of patients with NECs may range from very aggressive neoplasms killing patients in one/two months to NECs with a survival rate better than expected. It is difficult to identify these groups of patients on a purely morphological basis, but markers that may help in identifying these cases have recently been proposed for, at least, colonic NECs. The immunohistochemical expression of CD117 was found to be associated with a much worse outcome (56) and this finding has recently been confirmed by our group in a large series of GEP PD-NECs including more than 200 cases of different sites (unpublished results). Interestingly, c-kit gene mutation in CD117-immunoreactive colorectal NECs has never been demonstrated $(57,58)$ suggesting that in this cancer subset $\mathrm{CD} 117$ overexpression is not mediated via activating mutations and that imatinib mesylate (Glivec) therapy is not useful in these patients (59).

The simultaneous presence of microsatellite instability (MSI) and widespread gene methylation was found to be a predictor of a better outcome in patients with colorectal NECs (60) and we have recently confirmed this finding in a larger series including NECs of the entire tubular gut (unpublished results). The identification of this molecular subset may help in the prognostic stratification of patients. This specific molecular category of NECs is difficult to recognize morphologically, although the large cell subtype, an abundant peritumoral lymphoid infiltrate and the lack of both histologically documented vascular invasion and CD117 expression are frequently observed. Since there is a good correlation between MSI and the immunohistochemical loss of mismatch repairs proteins, we suggest that immunohistochemistry for MLH1, MSH2, MSH6, and PMS2 should be included in the diagnostic panel to identify unstable carcinomas potentially correlated with a better prognosis.

\section{NOMENCLATURE AND CLASSIFICATION}

\section{Naming Neuroendocrine Neoplasms}

The debate over the terms used to define neuroendocrine tumors goes back to the very beginning of $20^{\text {th }}$ century, when Siegfried Oberdorfer described a series of six tumors of the small intestine, which he called "carcinoid" (i.e. carcinoma-like) on the assumption that they were benign neoplastic proliferations (61). At that time, the endocrine nature of these lesions was unknown and there was disagreement also on their real neoplastic significance (62). It was Claude L. Pierre Masson, after he developed his argentaffin reaction, who concluded that carcinoid cells had an endocrine function, and called these tumors "argentaffinoma" (63). Forty-five years later, Antony G. E. Pearse proposed the APUD concept, showing that GEP endocrine cells were capable of amine precursor uptake and decarboxylation. He coined the term "APUDoma" for endocrine tumors derived from those cells, and suggested that APUD cells and related tumors were present also in non-intestinal sites (64). However, the term carcinoid has become very popular among pathologists and clinicians and has been widely used to define a wide spectrum of neuroendocrine neoplasms arising in the digestive system, but originating from several different neuroendocrine cell types. It has failed to adequately convey the variety of such tumors which show different morphological, biological, clinical and molecular features, in part related to their site of origin along the digestive system.

In 1995, Capella and coworkers proposed a new prognostic classification of GEP NENs, calling them "neuroendocrine tumors" (65) and since then the use of the term "carcinoid" has been discouraged in diagnostic practice in favor of "neuroendocrine tumor (NET)", maintaining the term carcinoid solely in the context of the "carcinoid syndrome" (66-68). Since then, with slight variation between endocrine and neuroendocrine, the nomenclature of these tumors has remained stable and the latest WHO classification of digestive tumors has readopted these terms (6).

\section{Classifying Neuroendocrine Neoplasms}

It soon became very clear that not all "carcinoids" were clinically benign. Therefore, there was a need to elaborate a classification scheme, capable of separating potentially aggressive carcinomas from indolent tumors. This need became even more apparent when therapeutic options increased in number and improved in effectiveness. The classification of GEP NENs has been revised several times during the last three decades, with the aim of providing pathologists and oncologists with a robust tool, by which they would be able to stratify different prognostic groups of tumors $(65,66,69)$. The current WHO classification is largely based on the guidelines proposed by the European Neuroendocrine Tumor Society $(22,23)$ and is composed of a grading classification and a site-specific staging system (6). Two main categories have been identified: neuroendocrine tumors (NETs), broadly corresponding to "carcinoid tumors" or "well differentiated neuroendocrine tumors/carcinomas" of previous classifications $(66,69)$ and neuroendocrine carcinomas (NECs), corresponding to poorly differentiated neuroendocrine carcinomas of the previous classification (66). NETs are further divided in two 
groups (G1 and G2) on the basis of the mitotic count $(<2$ per 10HPF or 2-20 per 10HPF, respectively) and/or Ki67 index $(<2 \%$ or $3-20 \%$, respectively). NECs present high mitotic count ( $>20$ per $10 \mathrm{HPF})$ and Ki67 index $(>20 \%)$ and, by definition, are graded G3 and include small cell and large cell subtypes (Figure 7A-C).

This classification, although easy to use, presents at least two critical points, which should be carefully addressed by the pathologist. First: the separation between NET G1 and NET G2, which are significantly different on prognostic grounds, relies only upon subtle differences in proliferation rate. For this reason, strict criteria for establishing mitotic count (mitotic figures counted in $50 \mathrm{HPF}, 1 \mathrm{HPF}=2 \mathrm{~mm}^{2}$ ) and Ki67 index (percentage of stained nuclei on 500-2000 cells, in areas of strongest labeling) have been proposed (see above paragraph on proliferation assessment). The second issue is about a subset of cases in which morphology and proliferation index are discordant. The distinction between well differentiated NETs and poorly differentiated NECs is straightforward in the overwhelming majority of cases. However, the application of the 2010 WHO classification has quickly highlighted the existence of a subset of cases with well to moderately differentiated morphology and high proliferation rate (mitotic count and/or Ki67 index) (19, 7072). This fact raises two questions: i) how should these cases be classified? Can we call them NEC G3, or should we add a category, such as "moderately differentiated NETs with high proliferation index", as has been done in the stomach (73) or, again, neuroendocrine tumors $\mathrm{G} 3$, as done in the pancreas? (41) ii) Are these cases prognostically different from NET G2 and NEC G3? While a definite answer to the former question is not available to date, several studies have shown that these cases have a worse overall survival than NET G2, but also a significantly better prognosis than poorly differentiated NECs and, in addition, they seem not to benefit from platinum-based therapy $(71,72,74,75)$. These results suggest that a new category including high-grade neuroendocrine neoplasms defined by a well differentiated morphology and high proliferation rate should be identified and introduced in a future classification scheme.

Mixed exocrine-neuroendocrine neoplasms of the GEP system have been defined in the 2010 WHO classification with the term "mixed adenoneuroendocrine carcinomas (MANECs)" (6). By definition, they are composed of both exocrine and neuroendocrine components (Figure 4) and each of them must represent at least $30 \%$ of the lesion. However, this term does not adequately convey the different types of mixed neoplasms. Indeed, both the exocrine and the neuroendocrine components can have
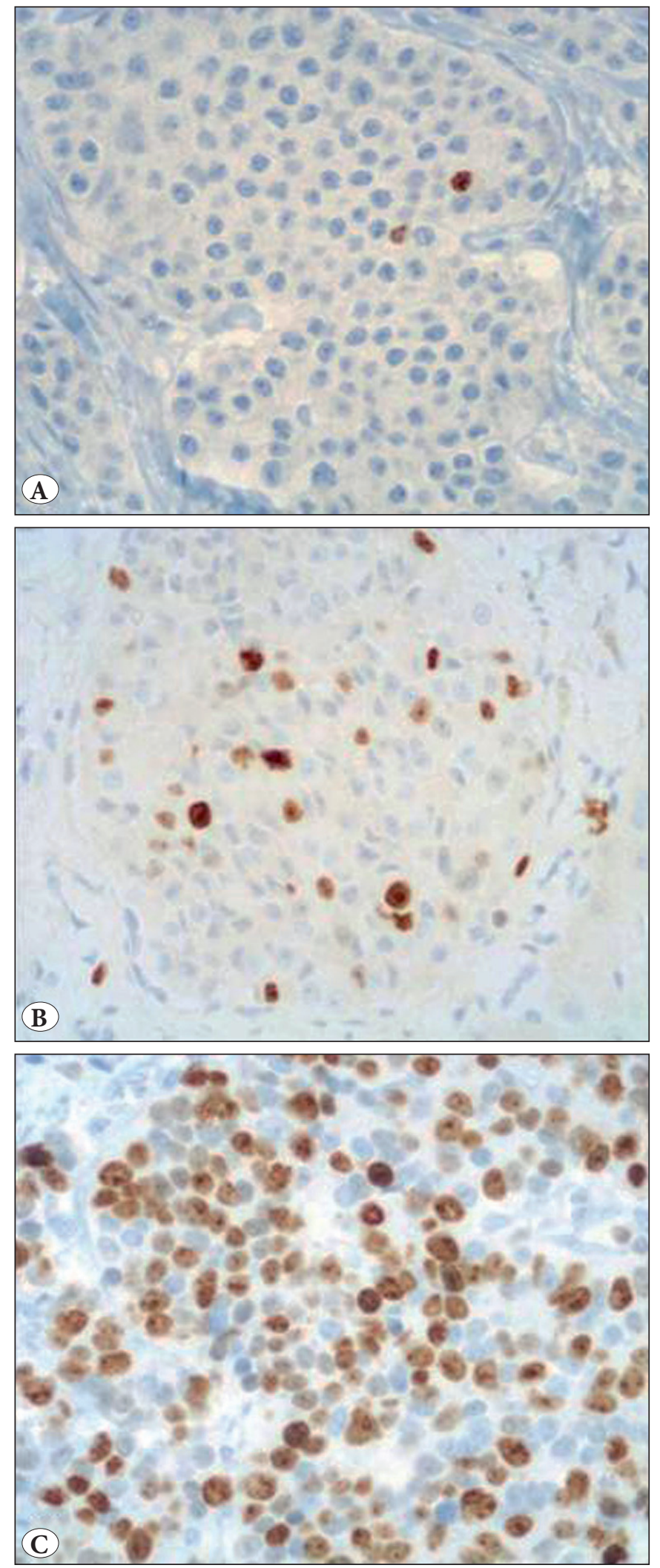

Figure 7: A) Ki67 index in a grade 1 well differentiated neuroendocrine tumor, B) in a grade 2 well differentiated neuroendocrine tumor, $\mathbf{C}$ ) and in a grade 3 neuroendocrine carcinoma. 
different morphological features ranging from adenomas to adenocarcinomas or squamous cell carcinomas in exocrine components and from well to poorly differentiated NENs in neuroendocrine components (8). The different combination of these tumor types gives rise to different prognostic categories ranging from indolent neoplasms composed of adenoma and NETG1 to very aggressive ones characterized by NECs associated with an exocrine component (adenoma, adenocarcinoma or squamous cell carcinoma). For this reason MANEC should not be considered as a unique entity but as a spectrum of different neoplastic diseases. We suggest modifying the term MANEC with "mixed adenoneuroendocrine neoplasms (MANENs)" or, better, "mixed neuroendocrine/non neuroendocrine neoplasms" which include the different tumor entities summarized in Table II.

Table II: Different types of mixed exocrine-neuroendocrine neoplasms, grouped according to the grade of malignancy. Modified from the paper by La Rosa et al.(8)

\begin{tabular}{|c|}
\hline Mixed Adenoneuroendocrine Neoplasms (MANENs) \\
\hline Mixed Adenoneuroendocrine Carcinoma (MANEC) \\
\hline High-grade malignant \\
Mixed adenoma/adenocarcinoma-NEC \\
Mixed squamous cell carcinoma-NEC \\
Intermediate grade malignant \\
Mixed adenocarcinoma-G1/G2 NET ${ }^{\star}$ \\
Mixed diffuse carcinoma-G1/G2 NET ${ }^{\star}$ \\
\hline Mixed Adenoneuroendocrine Tumor (MANET) \\
\hline Adenoma/NET \\
\hline
\end{tabular}

NEC: Poorly differentiated neuroendocrine carcinoma, *: G1-G2 according to WHO 2010 classification (6), NET: Neuroendocrine tumor.

\section{CONFLICT OF INTEREST}

The authors declare that they have no conflict of interest.

\section{REFERENCES}

1. Niederle MB, Hackl M, Kaserer K, Niederle B. Gastroenteropancreatic neuroendocrine tumours: The current incidence and staging based on the WHO and European Neuroendocrine Tumour Society classification: An analysis based on prospectively collected parameters. Endocr Relat Cancer. 2010;17:909-18.

2. Yao JC, Hassan M, Phan A, Dagohoy C, Leary C, Mares JE, Abdalla EK, Fleming JB, Vauthey JN, Rashid A, Evans DB. One hundred years after "carcinoid": Epidemiology of and prognostic factors for neuroendocrine tumors in 35,825 cases in the United States. J Clin Oncol. 2008;26:3063-72.
3. Mancuso K, Kaye AD, Boudreaux JP, Fox CJ, Lang P, Kalarickal PL, Gomez S,Primeaux PJ. Carcinoid syndrome and perioperative anesthetic considerations. J Clin Anesth. 2011;23:329-41.

4. La Rosa S, Franzi F, Albarello L, Schmitt A, Bernasconi B, Tibiletti MG, Finzi, G, Placidi C, Perren A, Capella C. Serotonin-producing enterochromaffin cell tumors of the pancreas: Clinicopathologic study of 15 cases and comparison with intestinal enterochromaffin cell tumors. Pancreas. 2011;40:883-95.

5. Rindi G, Bordi C, La Rosa S, Solcia E, Delle Fave G Gastroenteropancreatic (neuro) endocrine neoplasms: The histology report. Dig Liver Dis. 2011;43 Suppl 4:356-60.

6. Rindi G, Arnold R, Bosman FT, Capella C, Klimstra DS, Klöppel G, Komminoth P, Solcia E. Nomenclature and classification of neuroendocrine neoplasms of the digestive system. In: Bosman FT, Carneiro F, Hruban RH, Theise ND, editors. WHO classification of tumours of the digestive system. Lyon: IARC Press; 2010. 13-4.

7. Capella C, La Rosa S, Uccella S, Billo P, Cornaggia M. Mixed endocrine-exocrine tumors of the gastrointestinal tract. Semin Diagn Pathol. 2000;17:91-103.

8. La Rosa S, Marando A, Sessa F, Capella C. Mixed adenoneuroendocrine carcinomas (MANECs) of the gastrointestinal tract: An update. Cancers. 2012;4:11-30.

9. Volante M, La Rosa S, Castellano I, Finzi G, Capella C, Bussolati G. Clinico-pathological features of a series of 11 oncocytic endocrine tumours of the pancreas. Virchows Arch. 2006;448:545-51.

10. Singh R, Basturk O, Klimstra DS, Zamboni G, Chetty R, Hussain S, La Rosa S, Yilmaz A, Capelli P, Capella C, Cheng JD, Adsay NV. Lipid-rich variant of pancreatic endocrine neoplasms. Am J Surg Pathol. 2006;30:194-200.

11. La Rosa S, Finzi G, Puppa G, Capella C. Lipid-rich variant of appendiceal well differentiated neuro-endocrine tumor (carcinoid). Am J Clin Pathol. 2010;133:809-14.

12. Zee SY, Hochwald SN, Conlon KC, Brennan MF, Klimstra DS. Pleomorphic pancreatic endocrine neoplasms: A variant commonly confused with adenocarcinoma. Am J Surg Pathol. 2005;29:1194-200.

13. Soga J, Tazawa K. Pathologic analysis of carcinoids: Histologic evaluation of 62 cases. Cancer. 1971;28:990-8.

14. Plöckinger U, Rindi G, Arnold R, Eriksson B, Krenning EP, de Herder WW, Goede A, Caplin M, Oberg K, Reubi JC, Nilsson O, Delle Fave G, Ruszniewski P, Ahlman H, Wiedenmann B; European Neuroendocrine Tumour Society. Guidelines for the diagnosis and treatment of neuroendocrine gastrointestinal tumours. A consensus statement on behalf of the European Neuroendocrine Tumour Society (ENETS). Neuroendocrinology. 2004;80:394-424.

15. Klimstra DS, Modlin IR, Coppola D, Lloyd RV, Suster S. The pathologic classification of neuroendocrine tumors: A review of nomenclature, grading, and staging systems. Pancreas. 2010;39:707-12.

16. Lloyd RV. Practical markers used in the diagnosis of neuroendocrine tumors. Endocr Pathol. 2003;14:293-301. 
17. Wick MR. Immunohistology of neuroendocrine and neuroectodermal tumors. Semin Diagn Pathol. 2000;17:194-203.

18. DeLellis RA, Shin SJ, Treaba DO. Immunohistology of endocrine tumors. In: Dabbs DJ, editor. Diagnostic immunohistochemistry: Theranostic and genomic applications. Philadelphia: Saunders Elsevier; 2010. 291-339.

19. La Rosa S, Sessa F. High-grade poorly differentiated neuroendocrine carcinomas of the gastroenteropancreatic system: From morphology to proliferation and back. Endocr Pathol. 2014;25:193-8.

20. La Rosa S, Marando A, Gatti G, Rapa I, Volante M, Papotti M, Sessa F, Capella C. Achaete-scute homolog 1 as a marker of poorly differentiated neuroendocrine carcinomas of different sites: A validation study using immunohistochemistry and quantitative real-time polymerase chain reaction on 335 cases. Hum Pathol. 2013;44:1391-99.

21. Klimstra DS, Modlin IR, Adsay NV, Chetty R, Deshpande V, Gönen M, Jensen RT, Kidd M, Kulke MH, Lloyd RV, Moran C, Moss SF, Oberg K, O’Toole D, Rindi G, Robert ME, Suster S, Tang LH, Tzen CY, Washington MK, Wiedenmann B, Yao J. Pathology reporting of neuroendocrine tumors: Application of the Delphic consensus process to the development of a minimum pathology data set. Am J Surg Pathol. 2010;34:300-13.

22. Rindi G, Klöppel G, Alhman H, Caplin M, Couvelard A, de Herder WW, Erikssson B, Falchetti A, Falconi M, Komminoth P, Körner M, Lopes JM, McNicol AM, Nilsson O, Perren A, Scarpa A, Scoazec JY, Wiedenmann B; all other Frascati Consensus Conference participants; European Neuroendocrine Tumor Society (ENETS). TNM staging of foregut (neuro)endocrine tumors: A consensus proposal including a grading system. Virchows Arch. 2006;449:395-401.

23. Rindi G, Kloppel G, Couvelard A, Komminoth P, Korner M, Lopes JM, McNicol AM, Nilsson O, Perren A, Scarpa A, Scoazec JY, Wiedenmann B. TNM staging of midgut and hindgut (neuro) endocrine tumors: A consensus proposal including a grading system. Virchows Arch. 2007;451:757-62.

24. Rindi G, Petrone G, Inzani F. The 2010 WHO classification of digestive neuroendocrine neoplasms: A critical appraisal four years after its introduction. Endocr Pathol. 2014;25:186-92.

25. Draganova-Tacheva R, Bibbo M, Birbe R, Daskalakis C, Solomides C. The potential value of phosphohistone-h3 mitotic index determined by digital image analysis in the assessment of pancreatic endocrine tumors in fine-needle aspiration cytology specimens. Acta Cytol. 2013;57: 291-5.

26. Voss SM, Riley MP, Lokhandwala PM, Wang M, Yang Z. Mitotic count by phosphohistone $\mathrm{H} 3$ immunohistochemical staining predicts survival and improves interobserver reproducibility in well-differentiated neuroendocrine tumors of the pancreas. Am J Surg Pathol. 2015;39:13-24.

27. Scholzen T, Gerdes J. The Ki-67 protein: From the known and the unknown. J Cell Physiol. 2000;182:311-22.

28. Reid MD, Bagci P, Ohike N, Saka B, Erbarut Seven I, Dursun N, Balci S, Gucer, H, Jang KT, Tajiri T, Basturk O, Kong SY, Goodman M, Akkas G, Adsay V. Calculation of the Ki67 index in pancreatic neuroendocrine tumors: A comparative analysis of four counting methodologies. Mod Pathol. 2015;28:686-94.
29. Kaemmerer D, Posorski N, von Eggeling F, Ernst G, Hörsch D, Baum RP, Prasad V, Langer R, Esposito I, Klöppel G, Sehner S, Knösel T, Hommann M. The search for the primary tumor in metastasized gastroenteropancreatic neuroendocrine neoplasm. Clin Exp Metastasis. 2014;31:817-27.

30. La Rosa S, Rigoli E, Uccella S, Chiaravalli AM, Capella C. CDX2 as a marker of intestinal EC-cells and related well-differentiated endocrine tumors. Virchows Arch. 2004;445:248-54.

31. Erickson LA, Papouchado B, Dimashkieh H, Zhang S, Nakamura $\mathrm{N}$, Lloyd RV. Cdx2 as a marker for neuroendocrine tumors of unknown primary sites. Endocr Pathol. 2004;15:247-52.

32. Hermann G, Konukiewitz B, Schmitt A, Perren A, Klöppel G. Hormonally defined pancreatic and duodenal neuroendocrine tumors differ in their transcription factor signatures: Expression of ISL1, PDX1, NGN3, and CDX2. Virchows Arch. 2011;459: 147-54.

33. Schmitt AM, Riniker F, Anlauf M, Schmid S, Soltermann A, Moch H, Heitz PU, Klöppel G, Komminoth P, Perren A. Islet 1 (Isl1) expression is a reliable marker for pancreatic endocrine tumors and their metastases. Am J Surg Pathol. 2008;32:420-5.

34. Koo J, Mertens RB, Mirocha JM, Wang HL, Dhall D. Value of Islet 1 and PAX8 in identifying metastatic neuroendocrine tumors of pancreatic origin. Mod Pathol. 2012;25:893-901.

35. Graham RP, Shrestha B, Caron BL, Smyrk TC, Grogg KL, Lloyd $\mathrm{RV}$, Zhang L. Islet-1 is a sensitive but not entirely specific marker for pancreatic neuroendocrine neoplasms and their metastases. Am J Surg Pathol. 2013;37:399-405.

36. Koo J, Zhou X, Moschiano E, De Peralta-Venturina M, Mertens RB, Dhall D. The immunohistochemical expression of Islet 1 and PAX8 by rectal neuroendocrine tumors should be taken into account in the differential diagnosis of metastatic neuroendocrine tumors of unknown primary origin. Endocr Pathol. 2013;24: 184-90.

37. Folpe AL, Gown AM, Lamps LW, Garcia R, Dail DH, Zarbo RJ. Thyroid transcription factor-1: Immunohistochemical evaluation in pulmonary neuroendocrine tumors. Mod Pathol. 1999;12:5-8.

38. La Rosa S, Chiaravalli AM, Placidi C, Papanikolaou N, Cerati $\mathrm{M}$, Capella C. TTF1 expression in normal lung neuroendocrine cells and related tumors. Immunohistochemical study comparing two different monoclonal antibodies. Virchows Arch. 2010;457: 497-507.

39. Sangoi AR, Ohgami RS, Pai RK, Beck AH, McKenney JK, Pai RK. PAX8 expression reliably distinguishes pancreatic welldifferentiated neuroendocrine tumors from ileal and pulmonary well-differentiated neuroendocrine tumors and pancreatic acinar cell carcinoma. Mod Pathol. 2011;24:412-24.

40. Long KB, Srivastava A, Hirsch MS, Hornick JL. PAX8 expression in well-differentiated pancreatic endocrine tumors: Correlation with clinicopathologic features and comparison with gastrointestinal and pulmonary carcinoid tumors. Am J Surg Pathol. 2010;34:723-9. 
41. Agaimy A, Erlenbach-Wünsch K, Konukiewitz B, Schmitt AM, Rieker RJ, Vieth M, Kiesewetter F, Hartmann A, Zamboni G, Perren A, Klöppel G. ISL1 expression is not restricted to pancreatic well-differentiated neuroendocrine neoplasms, but is also commonly found in well and poorly differentiated neuroendocrine neoplasms of extrapancreatic origin. Mod Pathol. 2013;26:995-1003.

42. Kerr SE, Schnabel CA, Sullivan PS, Zhang Y, Huang VJ, Erlander MG, Brachtel EF, Dry SM. A 92-gene cancer classifier predicts the site of origin for neuroendocrine tumors. Mod Pathol. 2014;27:44-54.

43. Maecke HR, Reubi JC. Somatostatin receptors as targets for nuclear medicine imaging and radionuclide treatment. J Nucl Med. 2011;52:841-4.

44. Rufini V, Calcagni ML, Baum RP. Imaging of nuroendocrine tumors. Semin Nucl Med. 2006;36:228-47.

45. Papotti M, Kumar U, Volante M, Pecchioni C, Pate YC. Immunohistochemical detection of somatostatin receptor types 1-5 in medullary carcinoma of the thyroid. Clin Endocrinol. 2001;54:641-9.

46. Lambertini C, Barzaghi-Rinaudo P, D’Amato L, Schulz S, Nuciforo P, Schmid HA. Evaluation of somatostatin receptor subtype expression in human neuroendocrine tumors using two sets of new monoclonal antibodies. Regul Pept. 2013;187:35-41.

47. Volante M, Brizzi MP, Faggiano A, La Rosa S, Rapa I, Ferrero A, Mansueto G, Righi L, Garancini S, Capella C, De Rosa G, Dogliotti L, Colao A, Papotti M. Somatostatin receptor type 2A immunohistochemistry in neuroendocrine tumors: A proposal of scoring system correlated with somatostatin receptor scintigraphy. Mod Pathol. 2007;20:1172-82.

48. Real FX, Vila MR, Skoudy A, Ramaekers FC, Corominas JM. Intermediate filaments as differentiation markers of exocrine pancreas. II. Expression of cytokeratins of complex and stratified epithelia in normal pancreas and in pancreas cancer. Int J Cancer. 1993;54:720-7.

49. Bouwens L. Cytokeratins and cell differentiation in the pancreas. J Pathol. 1998;184:234-9.

50. Deshpande V, Fernandez-del Castillo C, Muzikansky A, Deshpande A, Zukerberg L, Warshaw AL, Lauwers GY. Cytokeratin 19 is a powerful predictor of survival in pancreatic endocrine tumors. Am J Surg Pathol. 2004;28:1145-53.

51. Schmitt AM, Anlauf M, Rousson V, Schmid S, Kofler A, Riniker F, Bauersfeld J, Barghorn A, Probst-Hensch NM, Moch H, Heitz PU, Klöppel G, Komminoth P, Perren A. WHO 2004 criteria and CK19 are reliable prognostic markers in pancreatic endocrine tumors. Am J Surg Pathol. 2007;31:1677-82.

52. La Rosa S, Rigoli E, Uccella S, Novario R, Capella C. Prognostic and biological significance of cytokeratin 19 in pancreatic endocrine tumours. Histopathology. 2007;50:597-606.

53. Zhang L, Smyrk TC, Oliveira AM, Lohse CM, Zhang S, Johnson MR, Lloyd RV. KIT is an independent prognostic marker for pancreatic endocrine tumors: A finding derived from analysis of islet cell differentiation markers. Am J Surg Pathol. 2009;33: 1562-9.
54. Marinoni I, Kurrer AS, Vassella E, Dettmer M, Rudolph T, Banz V, Hunger F, Pasquinelli S, Speel EJ, Perren A. Loss of DAXX and ATRX are associated with chromosome instability and reduced survival of patients with pancreatic neuroendocrine tumors. Gastroenterology. 2014;146:453-60.

55. Stefanoli M, La Rosa S, Sahnane N, Romualdi C, Pastorino R, Marando A, Capella C, Sessa F, Furlan D. Prognostic relevance of aberrant DNA methylation in g1 and g2 pancreatic neuroendocrine tumors. Neuroendocrinology. 2014;100:26-34.

56. La Rosa S, Marando A, Furlan D, Sahnane N, Capella C. Colorectal poorly differentiated neuroendocrine carcinomas and mixed adenoneuroendocrine carcinomas: Insights into the diagnostic immunophenotype, assessment of methylation profile, and search for prognostic markers. Am J Surg Pathol. 2012;36:601-11.

57. Akintola-Ogunremi O, Pfeifer JD, Tan BR, Yan Y, Zhu X, Hart J, Goldblum JR, Burgart L, Lauwers GY, Montgomery E, Lewin D, Washington K, Bronner M, Xiao SY, Greenson JK, Lamps L, Lazenby A, Wang HL. Analysis of protein expression and gene mutation of c-kit in colorectal neuroendocrine carcinomas. Am J Surg Pathol. 2003;27:1551-8.

58. Ishikubo T, Akagi K, Kurosumi M, Yamaguchi K, Fujimoto T, Sakamoto H, Tanaka Y, Ochiai A. Immunohistochemical and mutational analysis of c-kit in gastrointestinal neuroendocrine cell carcinoma. Jpn J Clin Oncol. 2006; 36:494-8.

59. Gross DJ, Munter G, Bitan M, Siegal T, Gabizon A, Weitzen R, Merimsky O, Ackerstein A, Salmon A, Sella A, Slavin S; Israel Glivec in Solid Tumors Study Group. The role of imatinib mesylate (Glivec) for treatment of patients with malignant endocrine tumors positive for c-kit or PDGF-R. Endocr Relat Cancer. 2006;13:535-40.

60. Sahnane N, Furlan D, Monti M, Romualdi C, Vanoli A, Vicari E, Solcia E, Capella C, Sessa F, La Rosa S. Microsatellite unstable gastrointestinal neuroendocrine carcinomas: A new clinicopathologic entity. Endocr Relat Cancer. 2015;22:35-45.

61. Oberndorfer S. Karzinoide tumoren des Dünndarms. Frankf Z Pathol. 1907;1:425-32.

62. Klöppel G. Oberndorfer and his successors: From carcinoid to neuroendocrine carcinoma. Endocr Pathol. 2007;18:141-4.

63. Masson P. Appendicite neurogéne and carcinoides. Ann Anat Pathol. 1924;1:3-59.

64. Pearse AG, Polak JM. Endocrine tumours of neural crest origin: Neurolophomas, apudomas and the APUD concept. Med Biol. 1974;52:3-18.

65. Capella C, Heitz PU, Hofler H, Solcia E, Klöppel G. Revised classification of neuroendocrine tumors of the lung, pancreas and gut. Virchows Arch. 1995;425:547-60.

66. Solcia E, Klöppel G, Sobin LH. Histological typing of endocrine tumours. WHO International Histological Classification of Tumours. $2^{\text {nd }}$ ed. Berlin: Springer; 2000.

67. DeLellis RA. The neuroendocrine system and its tumors: An overview. Am J Clin Pathol. 2001;115(suppl):S5-S16.

68. Chetty R. Requiem for the term "carcinoid tumour" in the gastrointestinal tract? Can J Gastroenterol. 2008;22:357-8.

69. Williams ED, Siebermann RE, Sobin LH. Histological typing of endocrine tumours. Geneva: World Health Organization; 1980. 
70. Reid MD, Balci S, Saka B, Adsay NV. Neuroendocrine tumors of the pancreas: Current concepts and controversies. Endocr Pathol. 2014;25:65-79.

71. Vélayoudom-Céphise FL, Duvillard P, Foucan L, Hadoux J, Chougnet CN, Leboulleux S, Malka D, Guigay J, Goere D, Debaere T, Caramella C, Schlumberger M, Planchard D, Elias D, Ducreux M, Scoazec JY, Baudin E. Are G3 ENETS neuroendocrine neoplasms heterogeneous? Endocr Relat Cancer. 2013;20:649-57.

72. Basturk O, Yang Z, Tang LH, Hruban RH, Adsay V, McCall CM, Krasinskas AM, Jang KT, Frankel WL, Balci S, Sigel C, Klimstra DS. The high-grade (WHO G3) pancreatic neuroendocrine tumor category is morphologically and biologically heterogeneous and includes both well differentiated and poorly differentiated neoplasms. Am J Surg Pathol. 2015;39:683-90.

73. La Rosa S, Inzani F, Vanoli A, Klersy C, Dainese L, Rindi G, Capella C, Bordi C, Solcia E. Histologic characterization and improved prognostic evaluation of 209 gastric neuroendocrine neoplasms. Hum Pathol. 2011;42:1373-84.
74. Sorbye H, Welin S, Langer SW, Vestermark LW, Holt N, Osterlund P, Dueland S, Hofsli E, Guren MG, Ohrling K, Birkemeyer E, Thiis-Evensen E, Biagini M, Gronbaek H, Soveri LM, Olsen IH, Federspiel B, Assmus J, Janson ET, Knigge U. Predictive and prognostic factors for treatment and survival in 305 patients with advanced gastrointestinal neuroendocrine carcinoma (WHO G3): The NORDIC NEC study. Ann Oncol. 2013;24:152-60.

75. Hijioka S, Hosoda W, Mizuno N, Hara K, Imaoka H, Bhatia V, Mekky MA, Tajika M, Tanaka T, Ishihara M, Yogi T, Tsutumi H, Fujiyoshi T, Sato T, Hieda N, Yoshida T, Okuno N, Shimizu Y, Yatabe Y, Niwa Y, Yamao K. Does the WHO 2010 classification of pancreatic neuroendocrine neoplasms accurately characterize pancreatic neuroendocrine carcinomas? J Gastroenterol. 2015;50:564-72. 